\title{
Pelatihan Pemanfaatan dan Pengembangan Bahan Ajar Digital Berbasis Multimedia Interaktif untuk Menghadapi Era Revolusi Industri 4.0
}

\author{
${ }^{1 *}$ Azhar Ahmad Smaragdina, ${ }^{2}$ Ahmad Mursyidun Nidhom, ${ }^{3}$ Dila Umnia Soraya, ${ }^{4}$ Rochmad Fauzi \\ Universitas Negeri Malang; Jalan Semarang 5 Malang \\ *Corresponding author: azhar.ahmad.ft@um.ac.id
}

\begin{abstract}
Abstrak
Kegiatan diperuntukkan guru-guru SMP di desa Turirejo Kec Lawang, dengan tujuan utama desa ini dapat menjadi pilot project dimana nantinya program pengabdian ini dapat berlanjut di beberapa desa di kecamatan yang lain. Era revolusi industri 4.0 telah membawa banyak perubahan pada berbagai aspek kehidupan dimana teknologi memiliki peranan yang sangat besar dan menjadi motor utama perubahan di setiap aspek. Guru idealnya memiliki kemampuan untuk mengembangkan bahan ajar dan media pembelajaran yang dapat diakses melalui perangkat digital, serta mampu memanfaatkan sumber-sumber belajar lain yang sesuai dengan karakteristik digital native. Hasil kegiatan telah dapat meningkatkan kapabilitas para guru dalam memanfaatkan dan mengembangkan bahan ajar digital berbasis multimedia interaktif, hal ini berdampak pada proses pembelajaran yang menjadi semakin variatif.
\end{abstract}

Kata kunci-bahan ajar digital, literasi digital, multimedia interaktif, pelatihan, revolusi industry 4.0.

\section{Abstract}

The activity is aimed at junior high school teachers in Turirejo village, Lawang district, with the main objective of this village being a pilot project where this community service program is needed to be continued in several villages in other sub-districts. The era of the industrial revolution 4.0 has brought many changes to various aspects of life while technology has a very big role and is the main motor of change in every aspect. The teacher ideally has the ability to develop teaching materials and learning media that can be accessed through digital devices, and be able to use other learning resources that are compatible with the original digital characteristics. The results of the activities have improved the ability of teachers to develop and develop interactive multimedia-based digital teaching materials, this has improved the learning process which has become increasingly varied.

Keywords - digital teaching materials, digital literacy, interactive multimedia, training, industrial revolution 4.0

\section{PENDAHULUAN}

$\mathrm{K}$ ecamatan Lawang merupakan Perangkat Daerah Kabupaten Malang yang mempunyai wilayah kerja sebanyak 12 (dua belas) Desa yaitu Desa Lawang, Desa Turirejo, Desa Ketindan, Desa Bedali, Desa Kalirejo, Desa Mulyoarjo, Desa Sidodadi, Desa Sidoluhur, Desa Srigading, Desa Sumber Ngepoh, Desa Sumber Porong, dan Desa Wonorejo. Berdasarkan data dari kemdikbud, kecamatan Lawang yang dikenal dengan daerah transit dan daerah perbatasan antara Malang dan Surabaya memiliki 79 satuan pendidikan mulai dari pendidikan tingkat dasar (SD/MI) sampai pendidikan tingkat atas (SMA/SMK/MA).

Menurut data observasi yang telah dilakukan peneliti, dari 79 satuan pendidikan di kecamatan
Lawang, khususnya di desa Turirejo, sebagian besar sekolah masih menggunakan menggunakan sumber belajar berupa buku cetak dan Lembar Kerja Siswa (LKS) yang dikeluarkan oleh diknas. Fakta ini memunculkan permasalahan dimana bahan ajar yang digunakan seharusnya lebih variatif dan sesuai dengan karakteristik peserta didik agar kegiatan pembelajaran dapat berjalan dengan lebih efektif sehingga dapat menghasilkan lulusan yang mampu bersaing di era revolusi industri 4.0.

Sebagaimana yang terjadi saat ini, era revolusi industri 4.0 telah membawa banyak perubahan pada berbagai aspek kehidupan dimana teknologi memiliki peranan yang sangat besar dan menjadi motor utama perubahan di setiap aspek. Perubahan yang massive ini tentunya juga berdampak pada

Page | 53 
bidang pendidikan, dimana cara belajar peserta didik pada era saat ini atau sering disebut dengan digital native, tentunya sangat berbeda dengan peserta didik di era sebelumnya. Karakteristik digital native (Prensky, 2001) terbiasa dengan struktur kognitif yang melompat-lompat, mampu melakukan beberapa kegiatan/tugas dalam waktu yang bersamaan, misalnya mendengarkan musik sambil membaca, dengan tetap dapat memahami bacaan yang dibacanya. Bagi digital native, teknologi digital (smartphone, komputer, internet) merupakan bagian dari kehidupan yang tidak dapat dipisahkan dari mereka (Mardiana, 2011). Generasi ini juga sangat mahir dalam menggunakan perangkat digital (Akcayir, 2016), dan lebih banyak menghabiskan waktunya dengan teknologi atau perangkat digital yang mereka miliki (Yong, 2014).

Karakteristik digital native yang khusus ini, tentunya akan sangat berdampak pada gaya belajar mereka. Generasi ini lebih mudah belajar dengan menggunakan tekonologi (Teo, 2013), dan lebih tertarik dengan bahan ajar dan media pembelajaran yang dapat mereka akses melalui perangkat digital seperti smartphone. Perubahan gaya belajar pada peserta didik yang hampir seluruhnya adalah generasi digital native, tentunya harus diimbangi dengan perubahan cara mengajar maupun bahan ajar yang digunakan oleh guru di kelas, sehingga kegiatan pembelajaran dapat berjalan dengan efektif dan capaian pembelajaran dapat tercapai sesuai dengan tujuan pembelajaran yang telah dirancang. Guru idealnya memiliki kemampuang untuk mengembangkan bahan ajar dan media pembelajaran yang dapat diakses melalui perangkat digital, serta mampu memanfaatkan sumbersumber belajar lain yang sesuai dengan karakteristik digital native.

Salah satu bahan ajar yang dapat memfasilitasi karakteristik dan gaya belajar generasi digital native adalah bahan ajar dan media pembelajaran berbasis multimedia interaktif, dimana bahan ajar ini menggabungkan beberapa jenis media (text, gambar, audio, animasi dan video) dan memberikan keleluasan bagi pengguna untuk berinteraksi dengan materi pada bahan ajar. Kelebihankelebihan yang dimiliki bahan ajar berbasis multimedia interaktif dinilai mampu memberikan pengalaman belajar yang berbeda bagi peserta didik, serta meningkatkan motivasi peserta didik untuk mempelajari materi-materi yang disediakan. Selain itu, bahan ajar ini juga sangat berpotensi untuk diintegrasikan dengan perangkat digital maupun teknologi internet yang sangat digemari oleh generasi digital native.
Berdasarkan beberapa permasalahan dan rasionalisasi yang telah diperikan sebelumnya, maka perlu diadakan pelatihan/workshop pengembangan bahan ajar digital berbasis multimedia interaktif bagi guru agar bahan ajar yang digunakan dalam kegiatan pembelajaran sesuai dengan karakteristik peserta didik. Melalui program pengabdian kepada masyarakat ini, tim pengusul berharap dapat memfasilitasi kegiatan pengembangan bahan ajar dan media pembelajaran berbasis multimedia interaktif khususnya di desa Turirejo Kec Lawang, dengan tujuan utama desa ini dapat menjadi pilot project dimana nantinya program pengabdian ini dapat berlanjut di beberapa desa di kecamatan yang lain.

Berdasarkan analisis situasi yang telah dijabarkan sebelumnya, maka dapat diidentifikasi dan dirumuskan beberapa permasalahan berikut ini: permasalahan utama yang ingin peneliti selesaikan adalah Secara khusus masalah yang akan diupayakan pemecahannya melalui program yang direncanakan ini adalah sebagai berikut, (1) Rendahnya persentase penggunaan bahan ajar digital yang sesuai dengan karakteristik siswa dan rendahnya kompetensi guru dalam upaya mengembangkan bahan ajar digital yang sesuai dengan karakteristik peserta didik (digital native). (2) Bagaimana meningkatkan kemampuan guruguru SMP di desa Turirejo Kecamatan Lawang dalam mengembangkan dan memanfaatkan bahan ajar digital berbasis multimedia interaktif yang sesuai dengan karakteristik peserta didik?

\section{METODE}

Metode yang digunakan dalam pelaksanaan pengabdian masyarakat ini dibagi dalam beberapa tahap pelaksanaan, yang meliputi tahap analisa kebutuhan, pembuatan modul pelatihan, validasi modul pelatihan, persiapan dan pengenalan, persiapan lingkungan teknis dan pelaksanaan workshop/pelatihan. Setiap detail tahapan dari metode pelaksanaan kegiatan PKM ini dijabarkan secara detail pada Gambar 1 berikut ini.

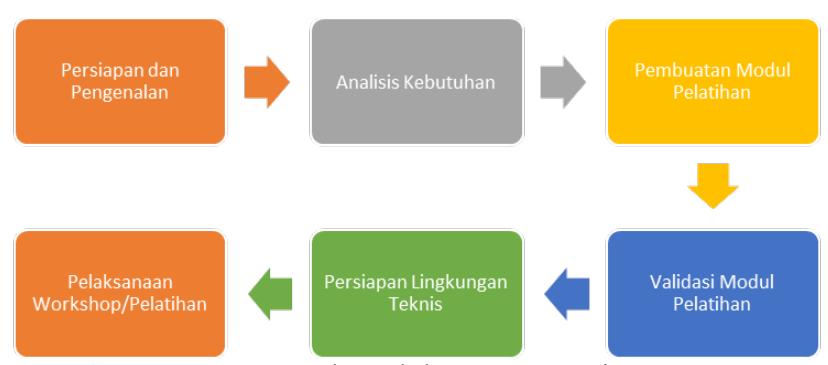

Gambar 1. Metode Pelaksanaan Kegiatan PKM 


\section{a. Persiapan dan Pengenalan}

Tahap persiapan dan pengenalan meliputi kegiatan pengenalan dan juga diskusi antara pihak sekolah dan tim pelaksana untuk sosialisasi program terhadap guru, maupun pihak struktural sekolah di kecamatan Lawang khususnya desa Turirejo tentang maksud, tujuan, dan metode pelaksanaan program.

\section{b. Analisis Kebutuhan}

Langkah selanjutnya pada kegiatan pengabdian ini adalah analisis data yang bertujuan untuk menganalisis kebutuhan media pembelajaran interaktif seperti apa yang sesuai dengan kegiatan pembelaran di SMP. Temuan-temuan hasil dari analisis kebutuhan ini nantinya dijadikan sebagai dasar pembuatan modul pelatihan.

\section{c. Pembuatan Modul Pelatihan}

Pada tahapan ini, modul pelatihan dirancang sesuai dengan data hasil temuan pada proses analisis data, dengan harapan modul yang dikembangkan sesuai dengan karakteristik peserta pelatihan dalam hal ini adalah guru SMP di desa Turirejo. Modul yang dikembangkan pada kegiatan PKM ini disusun dengan model project based learning dimana materi-materi mengenai pengembangan bahan ajar digital interaktif disertai dengan contoh project yang dapat dikembangkan oleh peserta pelatihan. Sehingga, para peserta pelatihan tidak hanya mendapatkan pengetahuan mengenai konsep bahan ajar digital tetapi juga mampu membuat bahan ajar digital sesuai dengan kebutuhan di sekolah.

\section{d. Validasi Modul}

Setelah modul pelatihan dikembangkan, tahap selanjutnya adalah validasi modul. Kegiatan validasi ini dilakukan dengan model peer review dengan harapan modul yang dikembangkan dapat ditelaah dan dicermati bersama. Kegiatan ini bertujuan untuk memastikan bahwa modul yang dikembangkan sudah terbebas dari kesalahan penulisan serta memiliki kelayakan untuk diterapkan pada kegiatan pelatihan.

\section{e. Persiapan Lingkungan Teknis}

Tahap ini digunakan oleh tim pelaksana untuk mempersiapkan segala kebutuhan khususnya kebutuhan teknis yang akan digunakan pada pelaksanaan workshop, mulai dari perlengkapan yang akan digunakan pada saat pelatihan, persiapan tempat pelatihan, ATK dan seminar kit yang dibutuhkan oleh peserta pelatihan.

\section{f. Pelaksanaan Workshop/Pelatihan}

Setelah lingkungan teknis sudah siap kegiatan selanjutnya adalah pelaksanaan workshop pengembangan bahan ajar dan media pembelajaran berbasis multimedia interaktif. Pelatihan ini dibagi menjadi beberapa tahapan, yaitu: 1) pengenalan bahan ajar dan media pembelajaran berbasis multimedia interaktif, 2) praktek pengembangan bahan ajar dan media pembelajaran berbasis multimedia interaktif; 3 ) evaluasi.

\section{HASIL DAN PEMBAHASAN}

Berdasarkan metode pelaksanaan Pengabdian Kepada Masyarakat, beberapa tahapan yang telah dilaksanakan oleh tim pelaksana kami perikan pada uraian berikut ini:

\section{a. Persiapan dan Pengenalan}

Tahapan awal dari kegiatan pengabdian ini meliputi kegiatan pengenalan dimana tim pelaksana melakukan diskusi dengan pihak sekolah dan stakeholder terkai. Kami mendapatkan respon yang baik dari pihak sekolah dan stakeholder mengenai rencana pelaksanaan kegiatan pelatihan kepada guruguru di desa Turirejo Kecamatan Lawang. Respon positif ini, memberikan semangat lebih kepada tim pelaksana untuk merealisasikan kegiatan pengabdian masyarakat dalam bentuk kegiatan pelatihan pengembangan dan pemanfaatan bahan ajar digital di era revolusi industri 4.0.

\section{b. Analisis Kebutuhan}

\section{Analisis karakteristik peserta didik}

Hasil analisis karakteristik peserta didik pada jenjang sekolah menengah pertama di desa Turirejo yang telah kami lakukan, menunjukkan bahwa seluruh peserta didik adalah generasi digital native yang sangat akrab dengan teknologi digital. Artinya, mereka sangat mahir dalam mengoperasikan perangkat-perangkat digital seperti komputer, laptop dan smartphone. Mereka juga sangat tertarik dengan bahan ajar digital, terlebih yang bersifat interaktif dimana mereka dapat berinteraksi dengan bahan ajar tersebut dan mendapatkan feedback secara langsung secara mandiri.

\section{Analisis lingkungan pembelajaran}

Pada tahapan ini, kamu juga melakukan analisis lingkungan pembelajaran. Berdasarkan hasil analisis yang telah kami lakukan, rata-rata guru pada sekolah menengah pertama di desa Turirejo belum menggunakan media pembelajaran interaktif atau bahan ajar digital untuk kegiatan pembelajaran. Buku dan modul masih menjadi sumber utama dalam kegiatan pembelajaran. Sementara fasilitas seperti LCD dan laptop sudah disediakan oleh sekolah. 
Bersumber dari hasil analisis karakteristik siswa dan analisis lingkungan pembelajaran, maka kebutuhan akan pemanfaatan dan penggunaan bahan ajar digital sangatlah tinggi. Karakteristik pesrta didik yang merupakan generasi digital native yang sangat akrab teknologi, memiliki ketertarikan yang tinggi terhadap penggunaan bahan ajar digital. Selain itu, fasilitas disekolah juga memungkinkan penggunaan bahan ajar digital pada kegiatan pembelajaran.

Beberapa alasan ini, semakin menguatkan kami untuk melakukan kegiatan pelatihan pemanfaatan dan pengembangan bahan ajar digital untuk guru-guru sekolah menengah dasar di desa Turirejo. Dengan harapan, kegiatan pembelajaran di sekolah-sekolah menengah pertama di desa Turireo lebih bervariasi. Bahan ajar digital maupun bahan ajar interaktif juga semakin banyak digunakan dalam kegiatan pembelajaran.

\section{c. Pembuatan Modul Pelatihan}

Modul pelatihan yang telah kami kembangkan, kami pecah ke dalam beberapa bagian dengan harapan dapat memudahkan pemahaman peserta pelatihan dan memudahkan proses evaluasi masing-masing topik yang akan disampaikan. Berikut ini rincian topik-topik bahasan pada modul pelatihan yang telah kami kembangkan.

Tabel 1. Deskripsi Modul yang Telah Dikembangkan

\begin{tabular}{|c|c|c|}
\hline No & Judul Modul & Deskripsi Topik \\
\hline 1 & $\begin{array}{l}\text { Pengenalan } \\
\text { Dasar Flash } \\
\text { dan Simbol }\end{array}$ & $\begin{array}{l}\text { Pengenalan dasar-dasar bahan ajar } \\
\text { digital berbasis mulitmedia } \\
\text { interaktif menggunakan aplikasi } \\
\text { Flash }\end{array}$ \\
\hline 2 & $\begin{array}{l}\text { Animasi } \\
\text { Dasar, } \\
\text { Masking dan } \\
\text { Motion Guide }\end{array}$ & $\begin{array}{l}\text { Pembuatan animasi dasar, } \\
\text { masking dan animasi motion } \\
\text { guide untuk pembelajaran }\end{array}$ \\
\hline 3 & $\begin{array}{l}\text { Animasi } \\
\text { Teks, Image } \\
\text { dan Audio }\end{array}$ & $\begin{array}{l}\text { Pembuatan animasi teks, animasi } \\
\text { menggunakan gambar, serta } \\
\text { penambahan audio pada media } \\
\text { pembelajaran }\end{array}$ \\
\hline 4 & $\begin{array}{l}\text { Proyek Media } \\
\text { Pembelajaran } \\
\text { dan Kuis } \\
\text { Interaktif }\end{array}$ & $\begin{array}{l}\text { Pembuatan proyek media } \\
\text { pembelajaran dengan } \\
\text { memanfaatkan komponen } \\
\text { mulitmedia (teks, gambar, audio } \\
\text { dan video) serta pembuatan kuis } \\
\text { interaktif }\end{array}$ \\
\hline
\end{tabular}

\section{d. Validasi Modul}

Validasi modul kami lakukan dengan model peer review, dimana kami juga tetap menggunakan instrumen dalam bentuk angket untuk memastikan modul yang dikembangkan sudah layak digunakan. Beberapa reviewer yang kami libatkan adalah ahli media pembelajaran dan ahli bahan ajar digital.
Berdasarkan hasil validasi dengan model peer review, kami telah melakukan beberapa perbaikan pada modul sesuai dengan masukan-masukan yang diberikan oleh ahli media pembelajaran dan ahli bahan ajar digital. Sehingga, secara keseluruhan modul yang telah dikembangkan untuk kegiatan pelatihan layak untuk digunakan oleh peserta pelatihan.

\section{e. Persiapan Lingkungan Teknis}

Tahap persiapan lingkungan teknis, juga telah kami lakukan untuk memastikan kegiatan pelatihan dapat berjalan dengan baik dan lancar. Beberapa kebutuhan teknis yang akan digunakan pada pelaksanaan workshop, mulai dari perlengkapan yang akan digunakan pada saat pelatihan, persiapan tempat pelatihan, ATK, laptop dan seminar kit yang dibutuhkan oleh peserta pelatihan juga sudah kami siapkan dengan baik.

\section{f. Pelaksanaan Workshop/Pelatihan}

Pelaksanaan kegiatan pelatihan dilakukan pada bulan Oktober 2019. Dengan konten Pengenalan Dasar Flash dan Symbol, Animasi Dasar, Masking dan Motion Guide Animasi Teks, Image Dan Audio Action Script 2.0 dan Proyek Media Pembelajaran Interaktif dan Kuis Interaktif Menggunakan Flash

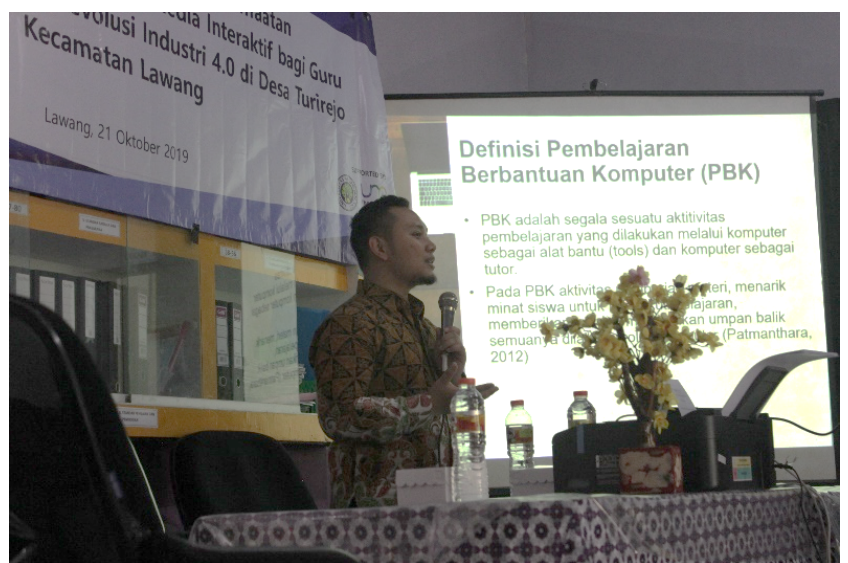

Gambar 2. Narasumber memberikan materi pelatihan

Kegiatan pelatihan kami lakukan dengan metode project based learning. Metode ini dinilai sangat sesuai untuk meningkatkan kompetensi guru dalam mengembangkan bahan ajar digital berbasis multimedia interaktif. Pada tahap awal narasumber memberikan materi-materi dasar (Gambar 2), kemudian narasumber memandu para guru untuk melakukan tahapan-tahapan kegiatan pemanfaatan dan pengembangan bahan ajar digital pada modul. 


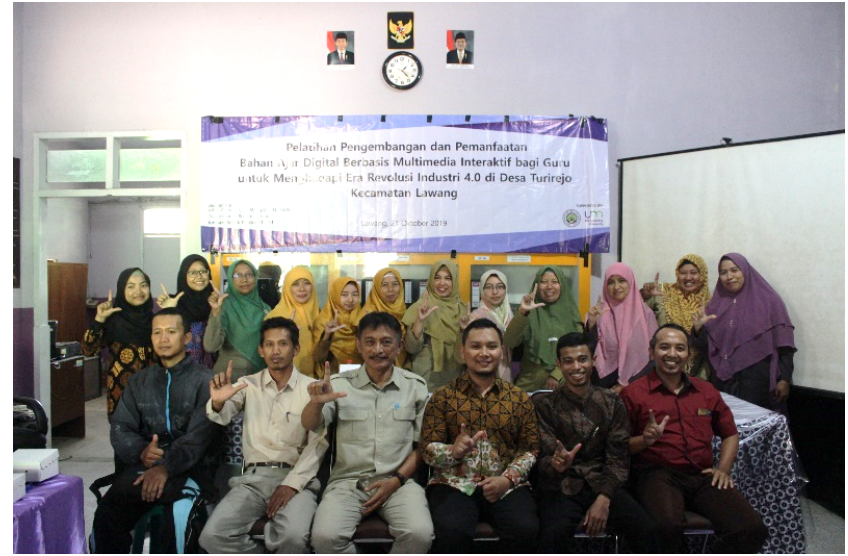

Gambar 3. Narasumber beserta para guru SMP

\section{SIMPULAN}

Kegiatan pelatihan pemanfaatan dan pengembangan bahan ajar digital berbasis multimedia interaktif telah kami lakukan sesuai dengan tahapan metode yang telah direncanakan. Dimana, kegiatan ini diharapkan mampu meningkatkan kapabilitas para guru dalam memanfaatkan dan mengembangkan bahan ajar digital berbasis multimedia interaktif. Hal ini tentunya akan berdampak pada proses pembelajaran yang menjadi semakin variatif. Selain itu, respon dari para guru juga sangat baik, dimana hal ini diindikasikan dengan antusiasme para guru saat mengikuti pelatihan serta feedback positif yang diberikan kepada pemateri. Tim pelaksana pengabdian berharap, pelatihan yang telah dilakukan dapat menstimulus para guru untuk terus mengembangkan diri dan berinovasi menciptakan bahan ajar yang sesuai dengan karakteristik peserta didik. Sehingga, kegiatan pembelajaran menjadi semakin berkualitas dan prestasi serta motivasi peserta didik semakin meningkat.

\section{DAFTAR RUJUKAN}

Akcayir, M., Hakan Dündar, Gökçe Akçayır. (2016). What makes you a digital native? Is it enough to be born after 1980? Computers in Human Behavior, 60 (July), pp. 435-440

Erenli, K. (2012). The impact of gamification: a recommendation of scenarios for education. In 15th International Conference on Interactive Collaborative Learning (ICL), 26-28 Sept. 2012 (pp. 1-8).
Grivokostopoulou F., Perikos, I., \& Hatzilygeroudis, I. (2016). "An Innovative Educational Environment Based on Virtual Reality and Gamification for Learning Search Algorithms," 2016 IEEE Eighth International Conference on Technology for Education (T4E), Mumbai, India, 2016, pp. 110-115.

Mardina, R. (2011). Potensi Digital Natives dalam Representasi Literasi Informasi Multimedia Berbasis Web di Perguruan Tinggi. Jurnal Pustakawan Indonesian, 11(1), 5-14

Moreno, J. (2012). Digital competition game to improve programming skills. Educ Technol Soc 15(3), 288-297 (2012)

Muntean, C. I. (2011). Raising engagement in elearning through gamification. In 6th International Conference on Virtual Learning ICVL (pp. 323-329)

$\mathrm{Ng}, \mathrm{W}$. (2012). Can we teach digital natives digital literacy? Computers and Education, 59(3), 10651078. doi:10.1016/j.compedu.2012.04.016

Prastiti, S. D., \& Sri Pujiningsih. (2009). Pengaruh Faktor Preferensi Gaya Belajar terhadap Prestasi Belajar Mahasiswa Akuntansi. Jurnal Ekonomi Bisnis, 14(3), 224-231

Prensky,M. (2001). Digital natives, digital immigrants part 1, On the horizon, 9 (5), pp. 1-6

Rachmad, A. N. (2015). Perilaku Konsumsi Surat Kabar pada Digital Native (Studi Deskriptif Perilaku Konsumsi Surat Kabar pada Remaja Usia 14-21 Tahun di Yogyakarta). Skripsi, Yogyakarta: Universitas Gadjah Mada

Rahadi, D.R., \& Zainal. (2015). Perilaku Pengguna Smartphone di Kalangan Mahasiswa Kota Palembang. Annual Research Seminar (ARS) Fakultas Ilmu Komputer UNSRI, hlm. 161-166.

Teo, T. (2013). An initial development and validation of a Digital Natives Assessment Scale (DNAS) Computers \& Education 67, pp. 51-57

Yong, S., \& Gates, P. (2014). Born digital: Are they really digital natives? International Journal of eEducation, eBusiness, e-Management and eLearning, 4(2), 102-n/a. doi:http://dx.doi.org/10.7763/IJEEEE.2014.V4.3 11 